\title{
Fertilizer Rate and Type Affect Sedum-vegetated Green Roof Mat Plant Performance and Leachate Nutrient Content
}

\author{
Mary Jane Clark and Youbin Zheng ${ }^{1}$ \\ School of Environmental Sciences, University of Guelph, 50 Stone Road East, \\ Guelph, Ontario, N1G 2W1, Canada; and Vineland Research and Innovation \\ Centre, 4890 Victoria Avenue North, Box 4000, Vineland Station, Ontario, \\ LOR 2E0, Canada
}

Additional index words. controlled-release fertilizer, green roof maintenance, living roof, mineral nutrition, nutrient runoff

\begin{abstract}
This study compared the effect of fertilizer rates and types on plant performance and leached nutrients for an installed sedum-vegetated green roof mat system. Sedumvegetated mats in non-fertilized plots (control) were compared with plots fertilized with 16N-2.6P-10K plus Minors 5-6 month controlled-release fertilizer (CRF) at 5, 10, 15, or $20 \mathrm{~g} \cdot \mathrm{m}^{-2}$ nitrogen (N) or $5 \mathrm{~g} \cdot \mathrm{m}^{-2} \mathrm{~N}$ of a fly-larvae processed chicken manure (Sus). Plot overall appearance was among the highest for $10 \mathrm{~g} \cdot \mathrm{m}^{-2} \mathrm{~N}$ in Mar., May, June, and July 2012, whereas 15 and $20 \mathrm{~g} \cdot \mathrm{m}^{-2} \mathrm{~N}$ resulted in the highest winter injury ranking in Mar. 2012. Vegetative coverage was highest for 10 and $15 \mathrm{~g} \cdot \mathrm{m}^{-2} \mathrm{~N}$ in Oct. 2011 but did not differ among treatments in 2012. Sedum spp. composition within plots remained closest to the original when fertilized at $10 \mathrm{~g} \cdot \mathrm{m}^{-2} \mathrm{~N}$. Of all species, $S$. acre flowered for the longest duration and flowered longer in $10 \mathrm{~g} \cdot \mathrm{m}^{-2} \mathrm{~N}$ than $15 \mathrm{~g} \cdot \mathrm{m}^{-2} \mathrm{~N}$ or Sus. Leaf greenness of $S$. acre for $5,10,15$, and $20 \mathrm{~g} \cdot \mathrm{m}^{-2} \mathrm{~N}$ was higher than the control in May 2012. Leached amounts of $\mathrm{NH}_{4}^{+}, \mathrm{NO}_{3}^{-}$, potassium (K), calcium (Ca), magnesium (Mg), sulfur (S), sodium $(\mathrm{Na})$, iron $(\mathrm{Fe})$, and aluminum $(\mathrm{Al})$ did not differ among treatments, and cadmium $(\mathrm{Cd})$, chromium $(\mathrm{Cr})$, copper $(\mathrm{Cu})$, mercury $(\mathrm{Hg})$, nickel $(\mathrm{Ni})$, and lead $(\mathrm{Pb})$ were not detected. All nutrients but $\mathrm{NO}_{3}{ }^{-}$in all plots and zinc $(\mathrm{Zn})$ in the $5 \mathrm{~g} \cdot \mathrm{m}^{-2} \mathrm{~N}$ (CRF and Sus) and control plots were leached at levels above target nutrient loss thresholds. Among fertilizer types, Sus leached more phosphorus (P) without greater plant performance compared with $5 \mathrm{~g} \cdot \mathrm{m}^{-2} \mathrm{~N}$ CRF. A fertilizer rate of $10 \mathrm{~g} \cdot \mathrm{m}^{-2} \mathrm{~N}$ is recommended to benefit plant performance of this green roof system. However, in the first year after installation, to prevent negative environmental impacts resulting from initial substrate fertility, no fertilizer (CRF or Sus) is needed for this green roof system.
\end{abstract}

Green roof installations have been increasing annually in North America, growing by $115 \%$ in 2011 alone (Green Roofs for Healthy Cities, 2012). The increase in green roof installations is likely the result of the many environmental, economic, and aesthetic benefits of green roofs, owing to the success of green roof vegetation (Barker and Lubell, 2012; Berndtsson, 2010; Oberndorfer et al., 2007). Green roof plants play an important role in optimal green roof functions

\footnotetext{
Received for publication 22 Oct. 2013. Accepted for publication 3 Jan. 2014.

This work was financially supported by the Ontario Ministry of Agriculture, Food and Rural Affairs/ University of Guelph Research Program, Landscape Ontario, Carrot Common, LiveRoof ${ }^{\circledR}$ Ontario Inc., and Sedum Master.

We thank Sedum Master for providing the plant material and Greg Yuristy, Katherine Vinson, Linping Wang, Mohammad Eftekhar, Thannushan Nimalendra, Arlin Otto, and Siobhan Dunets for their technical assistance.

${ }^{1}$ To whom reprint requests should be addressed e-mail yzheng@uoguelph.ca.
}

and contribute to green roof benefits (Dunnett et al., 2008; Morgan et al., 2012). However, few studies compare factors of the growing environment (i.e., substrate fertility) on both plant performance and the environmental impact of green roofs (Emilsson et al., 2007; Rowe et al., 2006).

Plant performance, as measured by plant survival, establishment, growth, and vegetative coverage (Clark and Zheng, 2012, 2013; Emilsson et al., 2007; FLL, 2008; Retzlaff et al., 2009; Zheng and Clark, 2013), is a significant factor for healthy, functioning green roofs. Both plant survival and establishment are critical for green roof functions with increased green roof benefits generally resulting from increased plant biomass (Rowe, 2011; Tan and Sia, 2009; Wolf and Lundholm, 2008). Vegetation coverage and density, evaluated through model simulations, have also shown an impact on green roof performance optimization (Currie and Bass, 2008; Sailor, 2008). Increased vegetative coverage causes increased roof shading, which reduces building cooling costs during the summer (Sailor, 2008). A high level of vegetative coverage is also recommended for weed suppression (Cook-Patton and Bauerle, 2012; Snodgrass and Snodgrass, 2006).

In addition, the environmental impact of green roofs is influenced by nutrient leaching to the environment. When above-optimum nutrient levels in the green roof growing environment are lost through runoff (i.e., leaching), green roofs can negatively impact the environment (Berndtsson, 2010). Water quality guidelines have been developed in Ontario (Ministry of the Environment and Energy, 1994) and Canada (Canadian Council of Ministers of the Environment, 2012) to ensure satisfactory surface and groundwater quality for protection of aquatic life and recreation. These documents can provide a target threshold for green roof runoff quality and environmental impact; however, green roof runoff is not governed by these regulations (Van Seters et al., 2009).

Within the growing environment, substrate composition and fertility influence both the plant performance and environmental impact of green roofs (Berndtsson, 2010; Fischer and Jauch, 2002). A suitable root zone environment (e.g., ideal growing substrate fertility and $\mathrm{pH}$ level) encourages healthy plant performance through nutrient availability (Jones, 2012). Since substrate fertility is either supplied by nutrient mineralization from growing substrate components or by applied fertilizer, to prevent leaching, total fertility from both sources should not exceed plant demand (Berndtsson, 2010; Gregoire and Clausen, 2011; Retzlaff et al., 2008). Below-optimal fertility levels can cause restricted plant growth, whereas high fertility can cause excessive plant growth or even toxicity and plant failure (Chen et al., 2001) as well as nutrient leaching.

In addition, plant growth response to substrate fertility can be influenced by climactic stress conditions (Barker and Lubell, 2012; Clark and Zheng, 2012). Regional climate conditions (e.g., precipitation and air temperature) influence nutrient availability within, and nutrient loss from, the growing substrate. Although fertilization recommendations for green roof maintenance have been suggested by FLL (2008), these recommendations need to be tested in diverse climactic regions using region-specific green roof systems. Thus, in addition to meeting, but not exceeding the fertility requirements of the vegetation, the components of the growing environment, within the region where the green roof is installed, are key factors in determining maintenance recommendations.

Green roof fertilization recommendations suggest annual applications of $5 \mathrm{~g} \cdot \mathrm{m}^{-2} \mathrm{~N}$ in the second and subsequent years after installation while considering the growing substrate fertility (FLL, 2008; Snodgrass and Snodgrass, 2006). Although green roof plants require nutrients during establishment, fertility of the initial growing substrate is assumed to supply adequate nutrition (Snodgrass and Snodgrass, 2006). Few studies have evaluated fertilizer application at installation instead of fertilization the next spring (Clark 
and Zheng, 2013; Emilsson et al., 2007). It is also recommended that if fertilizer is applied at installation, a consideration should be made to reduce nutrient leaching (FLL, 2008). Nutrient leaching is influenced by the growing substrate composition and thickness, roof age, and fertilizer type with higher nutrient loss occurring for substrates having high vs. low levels of compost or organic matter (Moran, 2004; Rowe et al., 2006), thin vs. thick substrate layers (Monterusso et al., 2004), young vs. old green roofs (Van Seters et al., 2009), or conventional vs. CRF applications (Emilsson et al., 2007). Because nutrient loss differs among commercial green roof substrates (Van Seters et al., 2009), field trials are needed to evaluate nutrient leaching from additional, especially newly-installed, green roof systems when nutrient leaching levels are expected to be the highest. Identification of an optimum fertilizer application rate for newly installed green roofs is needed to determine plant performance and environmental impact for green roofs with or without fertilizer added to the substrate. Leachate electrical conductivity (EC) and $\mathrm{pH}$ characterize the growing substrate and root zone environment. Leachate EC levels reflect the nutrient concentration in the root zone, whereas the $\mathrm{pH}$ levels influence the availability of these nutrients for uptake by plant roots (Jones, 2012; Zheng and Clark, 2013). The present study built on work by Clark and Zheng (2013) and Van Seters et al. (2009) by evaluating nutrient leaching for a longer time period after outdoor installation from a sedumvegetated green roof mat system.

Current recommendations suggest using CRFs to provide nutrients to green roof plants over the growing season (Snodgrass and Snodgrass, 2006). Additional fertilizer types, including conventional granular fertilizers, have also been used for green roof applications, because they can be more cost-effective than CRFs (Emilsson et al., 2007; Retzlaff et al., 2008). However, conventional fertilizers release nutrients quickly and, therefore, result in high levels of nutrient leaching compared with CRFs (Emilsson et al., 2007). In addition to granular conventional fertilizers, there is increasing interest in using organic and sustainable fertilizers on green roofs. However, plant performance and nutrient leaching data from green roofs fertilized with organic or sustainable fertilizers have limited representation in the literature (Clark and Zheng, 2013) and have not been reported for a sedum-vegetated mat green roof system. Therefore, this study will expand on previous work by evaluating the plant performance and nutrient loss from newly installed sedumvegetated mat green roof plots after fertilization with a fly larvae processed chicken manure sustainable fertilizer compared with CRFs. As well, few studies have been described in the literature that evaluate both green roof aesthetics in conjunction with functions and fertilizer rate (Clark and Zheng, 2012, 2013). The objectives of this study were to compare the effects of fertilizer rates and types on plant performance (as evaluated by vegetative coverage, overall appearance, winter injury, plant growth, flowering, and leaf color) and leached nutrients for an installed sedum-vegetated green roof mat system in climates similar to Ontario, Canada.

\section{Materials and Methods}

Plant material and treatments. A wooden, 1.56-cm-thick plywood box structure containing a sedum-vegetated mat green roof system was constructed on the roof outside the fifth floor of the Science Complex at the University of Guelph, Ontario, Canada (lat. $43^{\circ} 31^{\prime} 49^{\prime \prime} \mathrm{N}$, long. $80^{\circ} 13^{\prime} 44^{\prime \prime} \mathrm{W}$ ). The boxes measured $50 \mathrm{~cm} \times 50 \mathrm{~cm} \times 25 \mathrm{~cm}$ deep and were elevated $20 \mathrm{~cm}$ off the roof by two extended sides. The bottom of each box was sloped $\approx 4.0 \%\left(2.3^{\circ}\right)$ toward the center, where a funnel was secured into a drainage hole. The funnel spout was fit tightly into a hole in the lid of an 11.3-L plastic container positioned below the boxes for leachate collection. The 22-box wooden frame was arranged in a grid of $11 \times$ two boxes oriented with the long sides facing northwest and southeast. The 18 central boxes were used for treatment plots and the boxes on each end were designated as border plots to reduce edge effects. Each box was painted with one coat of Thompson's WaterSeal Advanced Maximum Strength One-Coat Waterproofer (Sherwin-Williams Canada Inc., Vaughan, Ontario, Canada) and lined with a 6-mm Vapor Barrier (Polytarp Products, Toronto, Ontario, Canada) with a slit cut for drainage.

The green roof system was installed inside the lined boxes in the following layers (bottom to top): 2.5 -cm-thick brown plastic drainage board (Sedum Master, Princeton, Ontario, Canada); DELTA ${ }^{\circledR}$-BIOTOP filter fabric (Cosella-Dorken Products, Inc., Beamsville, Ontario, Canada); 12.5-cm depth of Pre-Engineered Growing Medium (Sedum Master); and a vegetated Pre-Cultivated SMRM5 Sedum Blanket mat (Sedum Master). The substrate was comprised of $83 \%$ inorganic (i.e., sand, crushed brick) and 17\% organic material (i.e., peat, compost, and coir) with $5.8 \%$ air-filled porosity, $0.81 \mathrm{~g} \cdot \mathrm{cm}^{-2}$ dry bulk density, EC of $4493 \mu \mathrm{S} \cdot \mathrm{cm}^{-1}, \mathrm{pH}$ of 7.93 , and $62 \%$ volumetric water content. The substrate, subsampled at installation, contained $830.00 \mathrm{mg} \cdot \mathrm{kg}^{-1}$ total $\mathrm{N}$, i.e., total Kjeldahl $\mathrm{N}$ determined using a classical Kjeldahl digestion and a Skalar segmented flow autoanalyzer, and $\mathrm{NO}_{2}{ }^{-}$and $\mathrm{NO}_{3}{ }^{-}$determined using ion chromatography by SGS Agri-Food Laboratories, Guelph, Ontario, Canada, $810.00 \mathrm{mg} \cdot \mathrm{kg}^{-1}$ total $\mathrm{P}$, and $2200.00 \mathrm{mg} \cdot \mathrm{kg}^{-1}$ total $\mathrm{K}$. Both $\mathrm{P}$ and $\mathrm{K}$ were analyzed using a borate fusion-internal standard and X-ray fluorescence spectrometry method by SGS Laboratories, Lakefield, Ontario, Canada. The plant-available nutrient composition of the substrate was $283.00 \mathrm{mg} \cdot \mathrm{kg}^{-1} \mathrm{NO}_{3}{ }^{-}, 2.67$ $\mathrm{mg} \cdot \mathrm{kg}^{-1} \mathrm{P}$, and $263.03 \mathrm{mg} \cdot \mathrm{kg}^{-1} \mathrm{~K}$ (analyzed using a saturated paste extraction method by SGS Agri-Food Laboratories, Guelph, Ontario, Canada). The Pre-Cultivated SMRM5 Sedum Blanket mats were seeded with an evergreen sedum mix, which included: $S$. acre L., $S$. ellacombianum Praeger cvs., S. reflexum L., S. sexangulare L., and S. spurium Bieb. cvs. The sedum mats were grown in the Sedum Master field (Princeton, Ontario, Canada) using standard production practices until a saleable size was reached. Supplemental irrigation water $(\mathrm{pH} 8.0 \pm 0.4 ;$ EC $233.0 \pm$ $38.4 \mu \mathrm{S} \cdot \mathrm{cm}^{-1}$ ) from an on-site catchment pond was applied to the field as needed during production. On 4 July 2011, the sedum mats were cut into $50 \mathrm{~cm} \times 50$-cm squares, placed on the growing substrate in the wooden boxes, and each plot was watered by hand with $5 \mathrm{~L}$ of reverse osmosis (RO) water.

On 13 July 2011, three replications for each of six fertilizer rate treatments (Table 1) were applied to plots in a completely randomized design. Plots were left unfertilized (i.e., $0 \mathrm{~g} \cdot \mathrm{m}^{-2} \mathrm{~N}$ control) or fertilized with Agrium customized blend $16 \mathrm{~N}-2.6 \mathrm{P}-10 \mathrm{~K}$ plus Minors 5-6 month CRF (Agrium Advanced Technologies, Brantford, Ontario, Canada) applied at rates of $5,10,15$, and $20 \mathrm{~g} \cdot \mathrm{m}^{-2} \mathrm{~N}$ (further described as the $5,10,15$, 20 treatments) as well as $5 \mathrm{~g} \cdot \mathrm{m}^{-2} \mathrm{~N}$ of a $2.9 \mathrm{~N}$ $2.2 \mathrm{P}-2.3 \mathrm{~K}$ fly larvae processed chicken manure sustainable fertilizer (Sus; University of Guelph, Guelph, Ontario, Canada). For Sus, half of the amount $\left(2.5 \mathrm{~g} \cdot \mathrm{m}^{-2} \mathrm{~N}\right)$ was applied at each of two application times (i.e., 13 July and 7 Sept. 2011) to produce a nutrient availability similar to the $5 \mathrm{CRF}$ treatment.

Table 1. Fertilizer rates applied to sedum-vegetated green roof mats, resulting winter injury, and plot overall appearance rankings.

\begin{tabular}{|c|c|c|c|c|c|c|c|c|}
\hline \multirow[b]{2}{*}{ Treatment } & \multicolumn{3}{|c|}{ Rate $\left(\mathrm{g} \cdot \mathrm{m}^{-2}\right)^{\mathrm{z}}$} & \multirow{2}{*}{$\begin{array}{l}\text { Winter } \\
\text { injury }\end{array}$} & \multicolumn{4}{|c|}{2012 overall appearance ${ }^{x}$} \\
\hline & Nitrogen & Phosphorus & Potassium & & $\overline{\text { March }}$ & May & June & July \\
\hline Control & 0.0 & 0.0 & 0.0 & $1.7 \mathrm{~b}$ & $2.7 \mathrm{ab}$ & $4.7 \mathrm{~d}$ & $3.3 \mathrm{ab}$ & $4.0 \mathrm{c}$ \\
\hline Sus & 5.0 & 3.7 & 3.8 & $2.0 \mathrm{~b}$ & $2.0 \mathrm{a}$ & $4.3 \mathrm{~cd}$ & $3.3 \mathrm{ab}$ & $4.0 \mathrm{c}$ \\
\hline 5 & 5.0 & 0.8 & 3.1 & $2.0 \mathrm{~b}$ & $2.0 \mathrm{a}$ & $3.7 \mathrm{bcd}$ & $4.3 \mathrm{~b}$ & $4.3 \mathrm{c}$ \\
\hline 10 & 10.0 & 1.6 & 6.2 & $2.7 \mathrm{~b}$ & $2.7 \mathrm{ab}$ & $2.7 \mathrm{abc}$ & $2.7 \mathrm{ab}$ & $2.7 \mathrm{abc}$ \\
\hline 15 & 15.0 & 2.5 & 9.3 & $4.3 \mathrm{a}$ & $4.0 \mathrm{bc}$ & $2.3 \mathrm{ab}$ & $1.7 \mathrm{a}$ & $2.0 \mathrm{ab}$ \\
\hline 20 & 20.0 & 3.3 & 12.5 & $5.0 \mathrm{a}$ & $5.0 \mathrm{c}$ & $1.7 \mathrm{a}$ & $1.0 \mathrm{a}$ & $1.3 \mathrm{a}$ \\
\hline
\end{tabular}

${ }^{\mathrm{z}}$ Fertilized with Agrium customized blend $16 \mathrm{~N}-2.6 \mathrm{P}-10 \mathrm{~K}$ plus Minors 5-6 month controlled-release fertilizer or $5 \mathrm{~g} \cdot \mathrm{m}^{-2}$ nitrogen of a fly larvae processed chicken manure sustainable fertilizer (Sus).

${ }^{y}$ Ranked on a scale of 1 (least) to 5 (most) leaf desiccation damage. Means $(n=3)$ bearing the same letter are not significantly different at $P<0.05$ according to a Tukey's multiple comparison test.

${ }^{x}$ Ranked on a scale of 1 (most) to 5 (least) appealing. Means $(\mathrm{n}=3)$ bearing the same letter are not significantly different at $P<0.05$ according to a repeated-measures analysis of variance and Bonferroni post-test. 
Fertilizer was applied by spreading granules evenly over each plot by hand. Plots were watered with $\mathrm{RO}$ water by hand weekly or as needed to maintain plant health. Between 15 Aug. and 28 Oct. 2011 and 13 Mar. and 17 Aug. 2012, 11 and 10 rain events, respectively, produced leachate from plots. Mean monthly air temperatures ranged from 22.7 to $-2.9^{\circ} \mathrm{C}$ in July and Jan. 2012, respectively.

Measurements. Root zone $\mathrm{pH}$ and EC levels were monitored at monthly time points, between Aug. and Oct. 2011 and Mar. and Aug. 2012 by evaluating leachate characteristics. Leachate was obtained using $\mathrm{RO}$ water in a pour-through analysis following the method by Wright (1986) and was measured for $\mathrm{pH}$ and $\mathrm{EC}$ using a portable $\mathrm{pH}$ and $\mathrm{EC}$ meter (Oakton PC 300; Oakton Instruments, Vernon Hills, IL). After pour-through analysis and after rain events, total leachate volume was measured and a subsample was stored at $-80{ }^{\circ} \mathrm{C}$. Upon study completion, volumeweighted aliquots were combined in one container, mixed by stirring, and subsampled before elemental analysis was conducted using a Varian Vista Pro ICP-OES with an axially viewed plasma (Varian Inc., Australia) at the University of Guelph, Guelph, Ontario, Canada. Total nutrient loss $\left(\mathrm{N}_{\text {Loss }}\right)$ was calculated using the total leachate volume captured during the study $\left(\mathrm{V}_{\mathrm{Tot}}\right)$ and the volumeweighted nutrient concentration $\left(\mathrm{N}_{\mathrm{C}}\right)$ by the following equation: $\mathrm{N}_{\text {Loss }}=\mathrm{V}_{\text {Tot }} \cdot \mathrm{N}_{\mathrm{C}}$.

Responses of Sedum spp. to fertilizer treatments were evaluated in four areas: plot overall appearance and winter injury, vegetative coverage, plant growth and flowering, and leaf color. Overall appearance of a green roof provides a guideline of visual plant performance, plant health, and green roof success as perceived by the evaluator (Clark and Zheng, 2012, 2013; Rowe et al., 2006). Green roofs with a high overall appearance and low winter injury are the most desirable. Plot overall appearance was rated on a 1 (most appealing) to 5 (least appealing) scale per plot. Each rating was made relative to all other plots and was based on plant growth, color, visual appeal, and perceived plant health. Winter injury is influenced by shoot dieback and leaf desiccation and may result in plant failure (Boivin et al., 2001). Winter injury was rated on a 1 (best appearance resulting from the least injury) to 5 (worst appearance resulting from the most injury) scale per plot by visually estimating the percent of shoots per sedum species showing leaf desiccation on 15 Mar. 2012. Proportion vegetative coverage per plot was visually estimated overall and per species by comparing vegetation-covered with non-covered plot areas between July 2011 and Aug. 2012. The same observer evaluated overall appearance, winter injury, and vegetative coverage at all time points to ensure consistency. Shoot height can correspond to plant growth rate and vegetative coverage parameters on green roofs, and healthy plant growth is required to achieve green roof benefits (Dunnett et al., 2008; Morgan et al., 2012; Snodgrass and Snodgrass, 2006). Within plots, $S$. acre growth was most prevalent and best represented growth of any Sedum spp. in the current study. Therefore, shoot height was measured for three representative $S$. acre shoots per species per plot between July 2011 and Aug. 2012. Flowering increases the visual appeal of green roofs (Clark and Zheng, 2012) while providing a food source and urban habitat space for pollinators (Tonietto et al., 2011). The dates of the first and last open flower and number of inflorescence stems produced per species were recorded. Leaf tissue color of $S$. acre was quantitatively evaluated at three locations within each plot using a colorimeter (Minolta CR-310; Minolta Camera Co. Ltd., Osaka, Japan).

Statistical analysis. All data sets were analyzed using GraphPad Prism Version 5.03 software (GraphPad Software Inc., La Jolla, CA). One-way analysis of variance (ANOVA) was conducted for elemental amounts and concentrations, winter injury rankings as well as flower number and duration data with differences among means determined using a Tukey's multiple means comparison test. A Pearson correlation was conducted to compare winter injury and overall appearance rankings. A two-way repeated measures ANOVA with a Bonferroni post-test was used to evaluate differences among treatments over time. Regression analyses were used to relate nutrient concentration, vegetative coverage, shoot height, and leaf color to fertilizer rate and to estimate regression parameters for the best-fit regression model (linear or quadratic). All data were evaluated using a significance level of $P<0.05$.

\section{Results and Discussion}

\section{Plant performance}

Overall appearance and winter injury. Treatment and time did not have a significant effect, whereas the interaction of treatment and time did have a significant effect on plot overall appearance in 2012. In addition, sedum survived regardless of fertilizer treatment, similar to observations by Rowe et al. (2006). Overall appearance of the 10 treatment was midlevel at all time points, whereas the 20 treatment had among the best overall appearances in May, June, and July 2012, but among the worst overall appearances in Mar. 2012 of all treatments (Table 1). Conversely, the 5 and control treatments had among the best overall appearances in Mar. 2012 and among the worst overall appearances in May, June, and July 2012. Rowe et al. (2006) similarly observed a stressed appearance for unfertilized sedum plants. Plot overall appearance was positively correlated with winter injury in Mar. $2012\left(R^{2}=0.83, P<\right.$ $0.0001)$ and negatively correlated with winter injury in May, June, and July $2012\left(R^{2}=0.58\right.$, $P=0.0002 ; R^{2}=0.41, P=0.004 ; R^{2}=0.52$, $P=0.0008$, respectively). In Mar. 2012, high winter injury and leaf desiccation for all Sedum spp. in the 15 and 20 treatments influenced the low overall appearance ranking. Similarly, Boivin et al. (2001) identified that high fertilizer rates caused brown desiccated tissue in some sedum species. In the current study, winter injury was observed as white leaf tips for $S$. acre and $S$. sexangulare and as brown leaves for $S$. ellacombianum, S. reflexum, and S. spurium. As the 2012 growing season progressed (i.e., in May, June, and July 2012), the overall appearance was restored for treatments that previously showed winter injury. Therefore, the change from a positive to a negative correlation for overall appearance and winter injury over time in 2012 shows the ability of sedum to recover from winter injury. Overall, fertilization below $15 \mathrm{~g} \cdot \mathrm{m}^{-2} \mathrm{~N}$ is appropriate to prevent winter injury in the first year after installation for the green roof mat system in this study.

Vegetative coverage. At installation (i.e., July 2011), the initial mean proportion vegetative coverage was not significantly different among plots and averaged $0.71 \pm 0.05$. Between Oct. 2011 and Aug. 2012, total vegetative coverage was significantly influenced by time and treatment but not the interaction between time and treatment. Vegetative coverage among treatments differed in Oct. 2011 with the 15 and 10 treatments having among the highest coverage, but no difference in coverage was observed in 2012 (Fig. 1). By mid-July 2012, one of the 20 treatment plots had very tall stems, which fell over to result in some gaps in coverage. These observations suggest that fertilizing green roof mats at a rate of at least $10 \mathrm{~g} \cdot \mathrm{m}^{-2} \mathrm{~N}$ in the first year after installation could increase vegetation coverage faster than fertilizing at lower rates. However, this advantage diminished in the second year when maximum coverage was reached and fertilization at $20 \mathrm{~g} \cdot \mathrm{m}^{-2} \mathrm{~N}$ was disadvantageous. When per-species coverage was evaluated, $S$. acre and $S$. spurium were significantly influenced by time and treatment but not the interaction of time and treatment, whereas $S$. reflexum was only influenced by time. Vegetative coverage of $S$. acre increased for the 5,15 ,

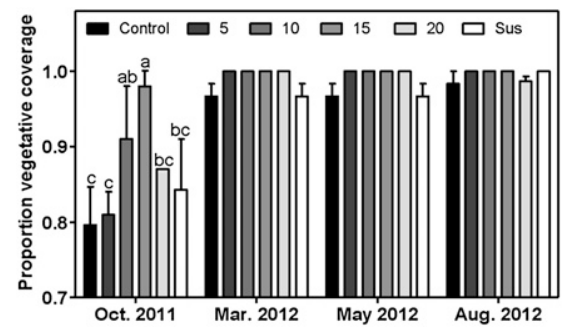

Fig. 1. Proportion total vegetative coverage for green roof plots from Oct. 2011 to Aug. 2012 fertilized with 0 (Control), $5,10,15$, or 20 , $\mathrm{g} \cdot \mathrm{m}^{-2}$ nitrogen $(\mathrm{N})$ of Agrium customized blend $16 \mathrm{~N}-2.6 \mathrm{P}-10 \mathrm{~K}$ plus Minors 5-6 month controlled-release fertilizer, or $5 \mathrm{~g} \cdot \mathrm{m}^{-2} \mathrm{~N}$ of a fly-larvae processed chicken manure sustainable fertilizer (Sus). For each time point, where the fertilizer application rate was significant $(P<0.05)$, bars bearing the same letter are not significantly different according to a twoway repeated-measures analysis of variance and Bonferroni post-test. Bars are means of three replications $\pm \mathrm{SE}$. 
and Sus treatments between Aug. 2011 and May 2012, whereas coverage of $S$. spurium decreased for all but the 5 and 10 treatments between Aug. and Oct. 2011 (Fig. 2). Therefore, of all treatments, species composition in the 10 treatment remained closest to the original composition over time. Although Barker and Lubell (2012) suggest adjusting cutting ratios to influence species composition proportions, this study indicates fertility adjustments may also contribute to achieving desired Sedum spp. proportions on green roofs. In addition, others have observed high green roof vegetative coverage preventing weed growth (Cook-Patton and Bauerle, 2012); however, few weeds grew within our treatment plots regardless of fertilizer rate.

Plant growth and flowering. Time, treatment, and the interaction between time and treatment had a significant effect on $S$. acre shoot height. Midrange shoot height was

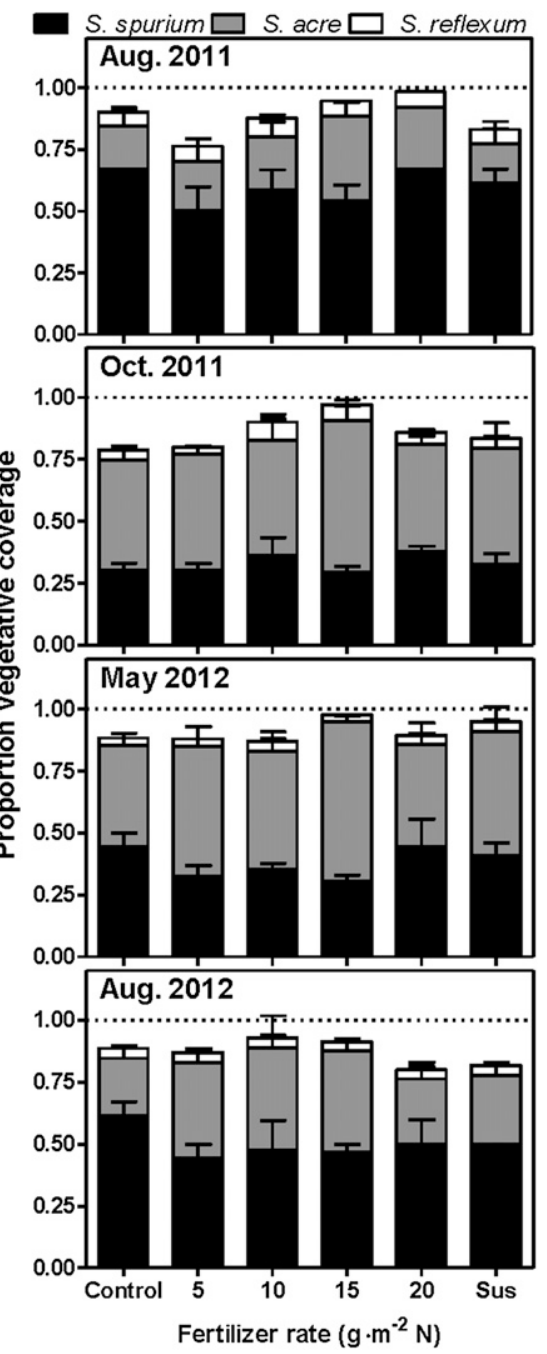

Fig. 2. Proportion vegetative coverage for three Sedum spp. grown in green roof plots from Aug. 2011 to Aug. 2012 fertilized with 0 (Control), 5, 10, 15 , or $20, \mathrm{~g} \cdot \mathrm{m}^{-2}$ nitrogen $(\mathrm{N})$ of Agrium customized blend $16 \mathrm{~N}-2.6 \mathrm{P}-10 \mathrm{~K}$ plus Minors 5-6 month controlled-release fertilizer, or $5 \mathrm{~g} \cdot \mathrm{m}^{-2} \mathrm{~N}$ of a fly-larvae processed chicken manure sustainable fertilizer (Sus). Bars are means of three replications per species \pm SE. observed for the 10 treatment vs. all other treatments at all time points (Fig. 3). No difference in shoot height among treatments occurred in Mar. 2012, but shoots were shorter in Mar. 2012 than in Sept. and Oct. 2011 and July 2012 for all treatments and in May 2012 for all but the control treatment. Short shoots in Mar. 2012 were likely caused by stem compaction by snow or stems rooting where they contacted the substrate. By late Aug. 2012, all the 20 and two of the 15 treatment plots had leaves dying and dropping off the lower part of shoots for all Sedum spp. This lower-leaf dieback may have been caused by shading from the dense top growth or poor air circulation. Barker and Lubell (2012) also observed a similar response in sedum after high levels of fertilization. Therefore, in the green roof mat system used in this study, fertilization at rates less than $15 \mathrm{~g} \cdot \mathrm{m}^{-2} \mathrm{~N}$ is recommended to prevent leaf dieback resulting from lush shoot growth. Overall, even with high initial fertility in the growing substrate, fertilization influenced S. acre shoot height in both 2011 and 2012. Therefore, fertilization at installation may be necessary at appropriate rates to encourage green roof functions, contrary to suggestions by Snodgrass and Snodgrass (2006). In addition, supplemental fertilizer may be required to maintain plant growth over time because initial substrate fertility is reduced through plant uptake and leaching (Rowe, 2011).

Flowering duration for $S$. acre was longer in the 10 (i.e., $60 \mathrm{~d}$ ) than in the 15 and Sus (i.e., $45 \mathrm{~d}$ ) treatments. No difference in flowering duration among treatments was observed for $S$. spurium or $S$. sexangulare. When all treatments were considered, flowering duration was significantly different among all species (i.e., $51 \pm 2,33 \pm 3$, and $24 \pm 1 \mathrm{~d}$ for $S$. acre, $S$. spurium, and $S$. sexangulare, respectively). Further study is needed to determine how additional factors besides fertilizer rate (i.e., substrate water status, root health, etc.) influence flowering duration in Sedum spp. Inflorescence number did not differ among treatments for any species; however, for all treatments combined, more $S$. acre vs. $S$. spurium and $S$. sexangulare inflorescences were produced (i.e., $191 \pm 16$ vs. $7 \pm 1$ and $8 \pm 4$, respectively). The high fertility of the growing substrate likely influenced flowering duration and number, thereby reducing the impact of added fertilizer on sedum flowering. Flowering duration is an important factor to consider for the aesthetic value of a green roof (Benvenuti and Bacci, 2010) and may influence urban pollinator populations for which green roof flowers are a food source (Tonietto et al., 2011). Therefore, further research is needed to determine how substrate fertility specifically influences flowering duration for sedum.

Leaf color. Leaf color influences green roof visual appeal because plants with green leaves are perceived as healthier than those with red or yellow leaves (Clark and Zheng, 2012). Treatment, time, and the interaction of treatment and time had a significant effect on $S$. acre leaf color. Two months after fertilization (i.e., Sept. 2011), S. acre leaves were greener in the 20 vs. 10 treatment (Fig. 4). In May 2012, leaf greenness was greater for the $5,10,15$, and 20 treatments vs. the control and the 15 treatment vs. Sus. However, no color difference was observed among treatments in Mar. or July 2012 (i.e., mean hue angle of 94 and 112, respectively). Among time points, leaf greenness was lower in Mar. vs. Sept. 2011 for all treatments and in Mar. vs. May and July 2012 for all but the control and 10 treatments. Low leaf greenness was likely the result of remobilization of nutrients in leaves (Matile, 2000). By July 2012, multiple environmental stress factors may have caused low leaf greenness for the 10 and control treatments, e.g., mineral reallocation or lower $\mathrm{N}$ content (Lee et al., 2003; Vollenweider and Gunthardt-Goerg, 2005). Low fertility may have extended the duration of low leaf greenness levels in the control in May 2012; however, further research is needed to determine the specific influences causing leaf pigment changes in S. acre and other Sedum spp. The increase in leaf greenness for all CRF treatments vs. the control in May 2012 did not persist throughout the 2012 growing season; therefore, added fertilizer is

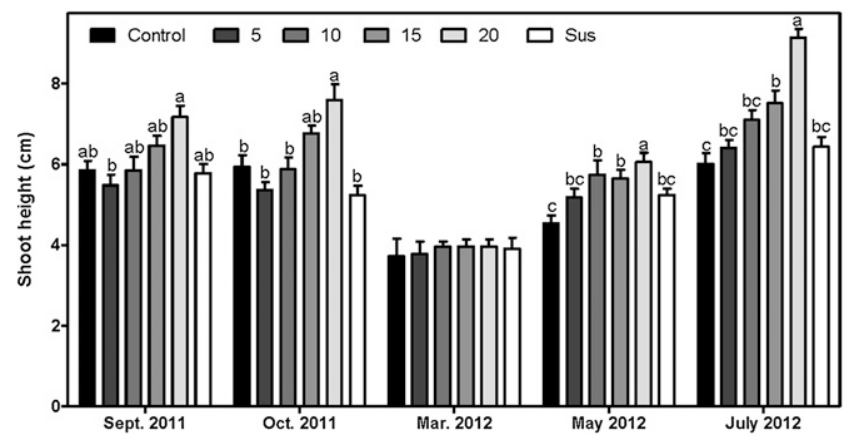

Fig. 3. Sedum acre shoot height in green roof plots during 2011 and 2012 fertilized with 0 (Control), 5, 10, 15 , or $20, \mathrm{~g} \cdot \mathrm{m}^{-2}$ nitrogen $(\mathrm{N})$ of Agrium customized blend $16 \mathrm{~N}-2.6 \mathrm{P}-10 \mathrm{~K}$ plus Minors 5-6 month controlled-release fertilizer, or $5 \mathrm{~g} \cdot \mathrm{m}^{-2} \mathrm{~N}$ of a fly-larvae processed chicken manure sustainable fertilizer (Sus). For each time point, where the fertilizer application rate was significant $(P<0.05)$, bars bearing the same letter are not significantly different according to a two-way repeated-measures analysis of variance with Bonferroni post-test. Bars are means of three replications $\pm \mathrm{SE}$. 
not recommended to solely increase leaf greenness in the first year after fertilization for this green roof system. Further research is needed to identify long-term effects of annual fertilization on leaf greenness for this and other green roof systems.

Leachate EC and $p H$. Time, but not fertilizer treatment or the interaction between time and treatment, had a significant effect on both leachate $\mathrm{pH}$ and EC collected from green roof plots. Leachate $\mathrm{pH}$ was greatest in Oct. 2011 (Fig. 5A) and greater at all time points than is recommended for plant growth in a soilless media (i.e., 5.6 to 6.2; Reed, $1996)$ or specifically for sedum growth (i.e., 6.43 or lower; Zheng and Clark, 2013).

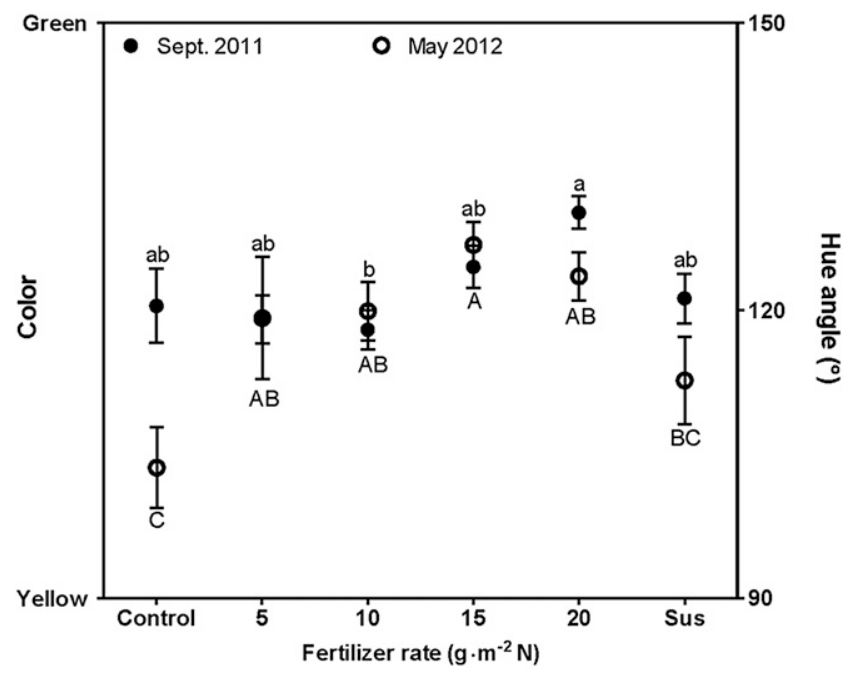

Fig. 4. Hue angle of $S$. acre tissue in green roof plots fertilized with 0 (Control), 5, 10, 15, or 20, g. $\mathrm{m}^{-2}$ nitrogen $(\mathrm{N})$ of Agrium customized blend $16 \mathrm{~N}-2.6 \mathrm{P}-10 \mathrm{~K}$ plus Minors 5-6 month controlled-release fertilizer, or $5 \mathrm{~g} \cdot \mathrm{m}^{-2} \mathrm{~N}$ of a fly larvae processed chicken manure sustainable fertilizer (Sus). For each time point, symbols bearing the same lowercase or uppercase letter are not significantly different at $P<$ 0.05 according to a two-way repeated-measures analysis of variance and Bonferroni post-test. Symbols represent the mean of nine replications $\pm \mathrm{SE}$.

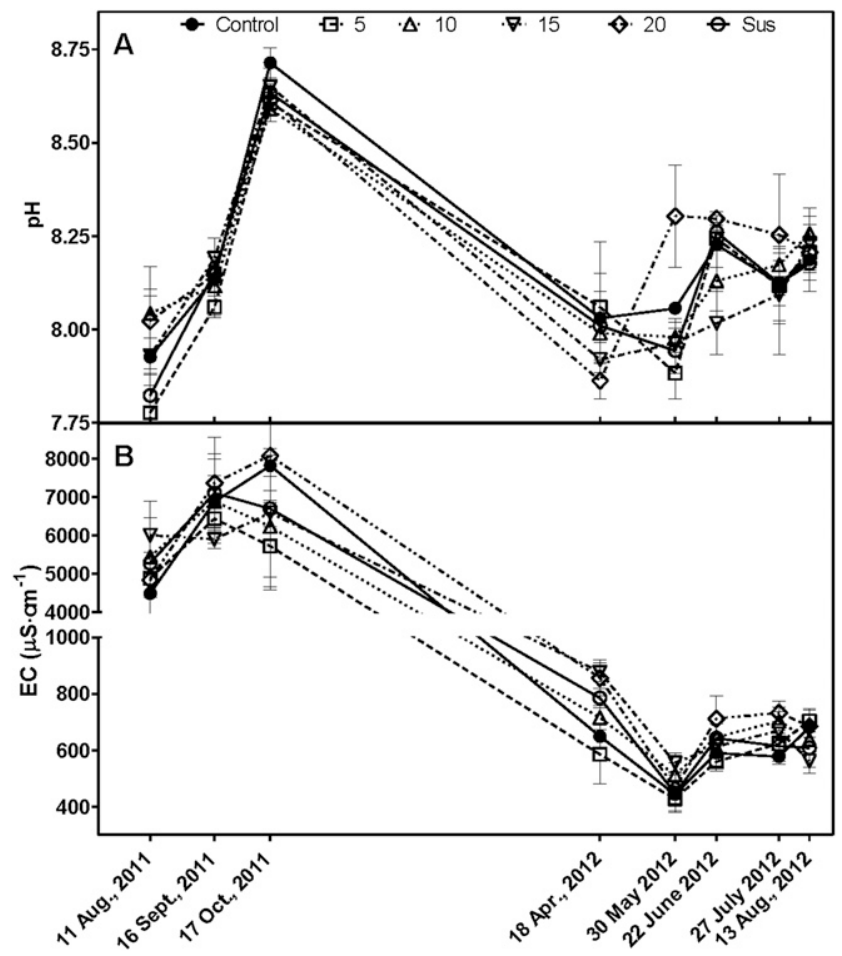

Fig. 5. Leachate $\mathrm{pH}(\mathbf{A})$ and electrical conductivity $(\mathrm{EC})(\mathbf{B})$ of green roof plots fertilized with 0 (Control), $5,10,15$, or $20, \mathrm{~g} \cdot \mathrm{m}^{-2}$ nitrogen $(\mathrm{N})$ of Agrium customized blend $16 \mathrm{~N}-2.6 \mathrm{P}-10 \mathrm{~K}$ plus Minors 5-6 month controlled-release fertilizer, or $5 \mathrm{~g} \cdot \mathrm{m}^{-2} \mathrm{~N}$ of a fly larvae processed chicken manure sustainable fertilizer (Sus). Symbols represent the mean of three replications \pm SE.
However, the $\mathrm{pH}$ was similar to other green roof systems (i.e., 7.9; Getter et al., 2007; Getter and Rowe, 2008; VanWoert et al., 2005; or 7.73 and 7.89; Nektarios et al., 2011) and still within the range generally suggested for green roofs (i.e., 6.0 to 8.5; FLL, 2008). In a preliminary study, this substrate had a high acid-buffering capacity, which may have contributed to the high leachate $\mathrm{pH}$ values. The $\mathrm{pH}$ buffering capacity of soil is influenced by the organic matter content (Marschner, 1995) and for green roof substrates can be influenced by aggregate materials such as crushed brick (Ampim et al., 2010; Dunnett et al., 2008). Although pH influences solubility of ions and thus absorption into plant roots (Russell, 1977), no distinct, characteristic nutrient-deficient symptoms were observed for the Sedum spp. as a result of the high $\mathrm{pH}$ during the course of the study.

Leachate EC was greater in Aug., Sept., and Oct. 2011 than all 2012 time points; however, no difference in EC occurred among 2012 time points (Fig. 5B). EC levels in 2011 were greater than the range recommended for healthy plant growth (i.e., 0.6 to $2.0 \mathrm{mS} \cdot \mathrm{cm}^{-1}$; Wright, 1986) but were within or below this range for 2012. Although the 2011 EC levels were higher in this study than in other green roof systems (Getter et al., 2007; Getter and Rowe, 2008; Nektarios et al., 2011; VanWoert et al., 2005), the 2012 EC levels in this study were lower than, or within range of, these systems. Further research is needed to identify sedum growth response to incremental increases in EC.

As a result of the high $\mathrm{pH}$ and $\mathrm{EC}$ in all treatments, substrate fertility and composition were likely among the main influences for these high levels. Compost can increase growing substrate $\mathrm{pH}$ and plant-available nutrient concentrations; however, the rate of nutrient availability from compost is controlled by environmental conditions (i.e., temperature and moisture; Kraus et al., 2000). The increase in leachate $\mathrm{pH}$ and high $\mathrm{EC}$, from Aug. to Oct. 2011, was likely influenced by nutrient release from compost within the green roof substrate. Nutrient concentration in the root zone can accumulate as a result of minimal nutrient leaching or if nutrient uptake is lower than nutrient supply. Between study initiation and the Oct. 2011 evaluation of root zone $\mathrm{pH}$ and EC, mean daily air temperature was $19.2 \pm$ $0.5{ }^{\circ} \mathrm{C}$, and only six irrigation events (i.e., rain or manual) caused leaching. Therefore, minimal leaching, in combination with nutrient release during the Aug. to Oct. 2011 warm air temperatures, likely caused nutrients to accumulate within the growing substrate. High substrate EC levels can negatively impact plant growth by reducing shoot elongation, flower production, and stem diameter or by increasing plant stress to cause lateral shoot production or flower abortion as observed for Lantana camara (Nektarios et al., 2004). Therefore, an optimal EC range should be identified and maintained for sedum growth on green roofs. The reduction in leachate EC between Oct. 2011 and Apr. 2012 was likely the result of nutrient leaching during winter 
freeze and thaw events. Although we did not find literature outlining the response to freeze and thaw events on nutrient loss within green roof or nursery production systems, an increase in $\mathrm{N}$ mineralization and potential $\mathrm{N}$ loss from arable land follows freeze and thaw events (Matzner and Borken, 2008). Therefore, using a growing substrate with $\mathrm{pH}$ and EC values within optimal ranges may increase sedum plant growth and flower production and minimize nutrient leaching.

Fertilizer rate for optimum plant performance. Based on plant performance data alone, a fertilizer rate of $10 \mathrm{~g} \cdot \mathrm{m}^{-2} \mathrm{~N}$ is recommended for application at installation to the sedum-vegetated mat green roof system used in this study. At rates below 10 and above $15 \mathrm{~g} \cdot \mathrm{m}^{-2} \mathrm{~N}$, no advantage for vegetative coverage was observed. At rates above $15 \mathrm{~g} \cdot \mathrm{m}^{-2}$ $\mathrm{N}$, sedum plants experienced winter injury damage, had lower leaf dieback, and S. acre had a shorter flowering duration than was observed after fertilization at $10 \mathrm{~g} \cdot \mathrm{m}^{-2} \mathrm{~N}$. In addition, Sedum spp. composition remained closest to the original when fertilized at $10 \mathrm{~g} \cdot \mathrm{m}^{-2} \mathrm{~N}$. Although previous recommendations have suggested fertilizing at $5 \mathrm{~g} \cdot \mathrm{m}^{-2} \mathrm{~N}$, plant performance for the sedum-vegetated mat green roof system in this study, grown in the Guelph, Ontario, Canada, climate, was ideal when fertilized at $10 \mathrm{~g} \cdot \mathrm{m}^{-2} \mathrm{~N}$.

\section{Environmental impact}

Nutrient leaching. Applying appropriate fertilizer rates to prevent nutrient leaching from green roofs prevents environmental pollution (Berndtsson, 2010) and reduces the cost of green roof maintenance compared with overfertilizing. Although nutrient levels in green roof runoff are not governed by provincial or federal guidelines in Canada (i.e., Canadian Council of Ministers of the Environment, 2012; Ministry of the Environment and Energy, 1994), these guidelines provide target levels that may prevent negative environmental impacts of green roof runoff (Van Seters et al., 2009).

Over the duration ( $400 \mathrm{~d}$ ) of this study, the total collected precipitation was $412.2 \mathrm{~mm}$ and average leachate volume collected per plot for all treatments was $329.4 \mathrm{~mm}$ (i.e., $20 \%$ retained). However, the higher fertilizer treatments tended to have less leachate than the lower fertilizer treatments. Over the study duration, $6 \%$ less leachate was lost from the 20 treatment compared with the control (data not shown). Although we observed lower rainwater retention levels than previous studies (i.e., up to $88 \%$ retention; Carter and Rasmussen, 2006), many factors including green roof characteristics, weather conditions, and rain intensity influence leachate quantity (Berndtsson, 2010). Further research is needed to evaluate the effects of fertilizer rate and type on leachate quantity for additional green roof installations.

Analysis of the volume-weighted leachate subsamples, combined from all time points, determined no detectable amounts of $\mathrm{Cd}, \mathrm{Cr}$, $\mathrm{Cu}, \mathrm{Hg}, \mathrm{Ni}$, or $\mathrm{Pb}$ in leachate from any treatment. Subsample analysis from all time points also resulted in no significant difference in the amount of $\mathrm{NH}_{4}^{+}, \mathrm{NO}_{3}^{-}, \mathrm{K}, \mathrm{Ca}$, $\mathrm{Mg}, \mathrm{S}, \mathrm{Na}, \mathrm{Fe}$, or $\mathrm{Al}$ observed among treatments (Fig. 6A). Among treatments, subsample analysis revealed the amount of $P$ leached was greatest for the Sus treatment, likely as a result of the amount of P supplied from both the growing substrate and fertilizer being above levels required for plant growth (Fig. 6B). Subsample analysis showed more $\mathrm{Zn}$ was leached in the 20 treatment than the 5, Sus, and control treatments, likely as a result of overapplication of $\mathrm{Zn}$ paired with low $\mathrm{Zn}$ levels required for sedum growth (Fig. 6B). For all other nutrients (i.e., $\mathrm{NH}_{4}^{+}, \mathrm{NO}_{3}^{-}, \mathrm{K}$, $\mathrm{Ca}, \mathrm{Mg}, \mathrm{S}, \mathrm{Na}, \mathrm{Fe}$, and $\mathrm{Al}$ ), because we observed no difference in leached nutrient amounts among treatments, substrate fertility and composition were likely among the main influences for nutrient leaching, as observed by Hathaway et al. (2008). Concentration of all nutrients except $\mathrm{Zn}$ in the 5, Sus, and control treatments, and $\mathrm{NO}_{3}{ }^{-}$in all treatments, were detected at levels that exceeded thresholds outlined in Ontario and Canadian guidelines for water quality (Canadian Council of Ministers of the Environment, 2012; Ministry of the Environment and Energy, 1994; Fig. 7). In previous research, Berndtsson et al. (2009) also concluded that P leached from extensive green roofs was from green roof soil materials as well as fertilizer, and $\mathrm{Zn}$ was a contaminant in leachate for some extensive green roof systems. Leached $P$ causes eutrophication (Correll, 1998), whereas leached
$\mathrm{Zn}$ is one cause of heavy metal contamination in soils, which decreases microbial biomass (e.g., mycorrhizal fungi; He et al., 2005). Conscientious environmental stewardship aims to eliminate excess $\mathrm{P}$ and $\mathrm{Zn}$ leaching to the environment. Over time, a decrease in leachate nutrient content may occur as nutrients in the growing substrate continue to be lost through leaching (Hathaway et al., 2008; Moran, 2004). Depending on the initial growing substrate composition and the rate at which nutrients are lost, application of CRF at installation may benefit plant performance without negative environmental impacts in some green roof systems. Rowe et al. (2006) also recommends a fertilizer application to sedum-vegetated green roofs and suggests reducing the amount of organic matter in green roof substrates to reduce "contaminated discharge." The growing substrate used in this study, having $17 \%$ organic matter and 830,810 , and $2200 \mathrm{mg} \cdot \mathrm{kg}^{-1}$ total $\mathrm{N}, \mathrm{P}$, and $\mathrm{K}$, respectively, had higher fertility than another commonly used green roof substrate (i.e., $6.8 \%$ organic matter and 204, 180, and $930 \mathrm{mg} \cdot \mathrm{kg}^{-1}$ total $\mathrm{N}, \mathrm{P}$, and $\mathrm{K}$, respectively; Clark and Zheng, 2013). Therefore, an adjustment of initial nutrient levels in the growing substrate and green roof system used in this study may reduce leachate nutrient levels to meet water quality guidelines and intentionally work toward environmental stewardship. This study emphasizes that green roof maintenance procedures should be sitespecific based on green roof components,
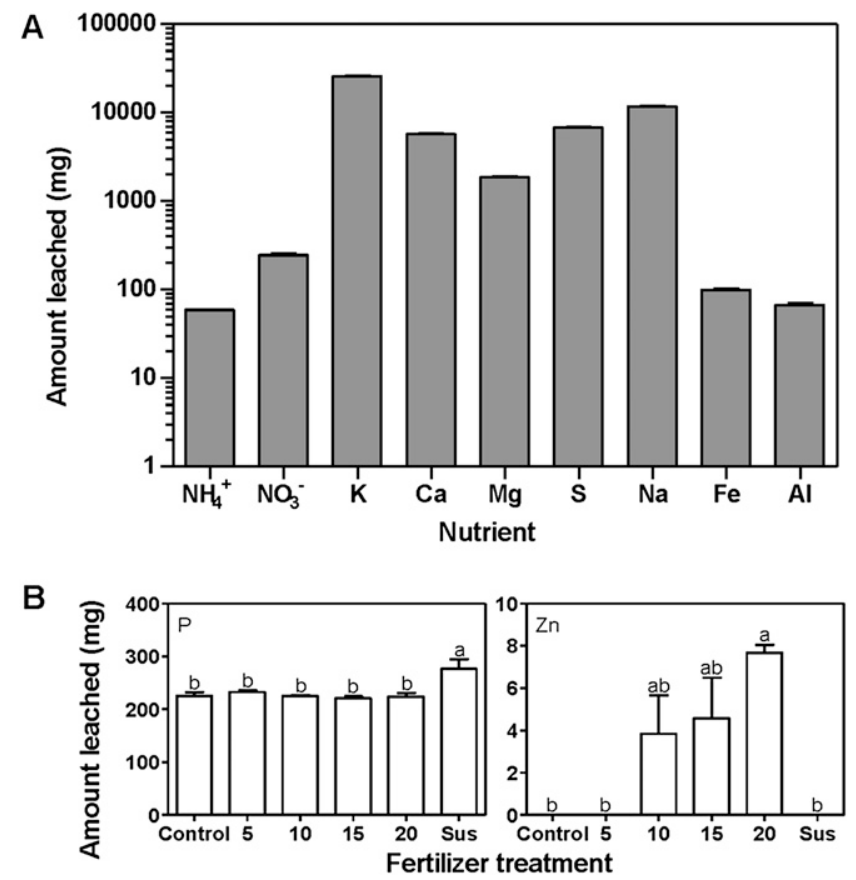

Fig. 6. Total amount of nutrients leached between July 2011 and Aug. 2012. A grouped mean is presented for nutrients with no difference among the majority of treatments (A), whereas an individual treatment mean is presented for phosphorus $(\mathrm{P})$ and zinc $(\mathrm{Zn})(\mathbf{B})$ when treatment effects were observed. Data are means \pm SE among individual (clear bars; $n=3$ ) or grouped (shaded bars; $n=18$ ) treatments fertilized with 0 (Control), 5, 10, 15 and $20 \mathrm{~g} \cdot \mathrm{m}^{2}$ nitrogen $(\mathrm{N})$ Agrium customized blend $16 \mathrm{~N}-2.6 \mathrm{P}-10 \mathrm{~K}$ plus Minors 5-6 month controlled-release fertilizer, or $5 \mathrm{~g} \cdot \mathrm{m}^{-2} \mathrm{~N}$ of a fly larvae processed chicken manure sustainable fertilizer (Sus). Bars bearing the same letter are not significantly different at $P<0.05$ according to a Tukey's multiple comparison test. 


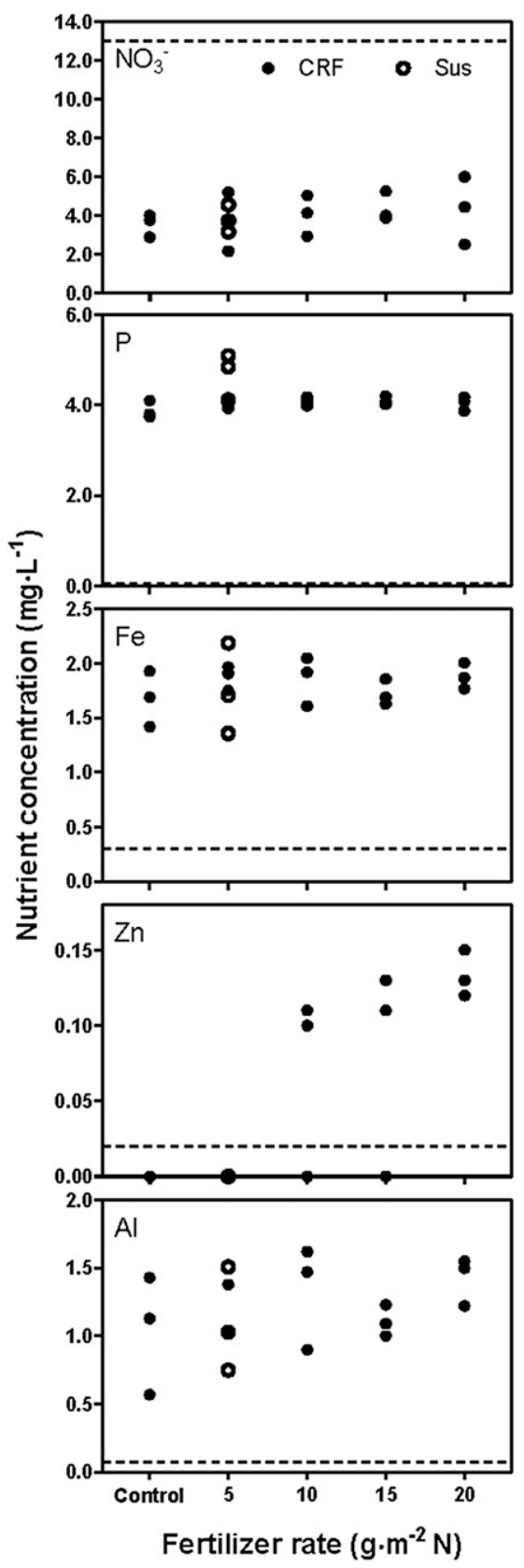

Fig. 7. Leachate nutrient concentration from volume-weighted samples collected between July 2011 and Aug. 2012 from green roof plots fertilized with 0 (Control), 5, 10, 15, or $20, \mathrm{~g} \cdot \mathrm{m}^{-2}$ nitrogen $(\mathrm{N})$ of Agrium customized blend $16 \mathrm{~N}-2.6 \mathrm{P}-10 \mathrm{~K}$ plus Minors 5-6 month controlled-release fertilizer (CRF), or $5 \mathrm{~g} \cdot \mathrm{m}^{-2}$ $\mathrm{N}$ of a fly-larvae processed chicken manure sustainable fertilizer (Sus). Symbols represent individual replicates. Dashed lines mark the upper threshold to meet Canadian (i.e., $\mathrm{NO}_{3}{ }^{-}$; Canadian Council of Ministers of the Environment, 2012) and Ontario [i.e., phosphorus (P), iron ( $\mathrm{Fe})$, zinc $(\mathrm{Zn})$, and aluminum (Al); Ministry of the Environment and Energy, 1994] water quality objectives.

especially growing substrates, to minimize negative environmental impacts. Further research is needed to test additional CRF rates and growing substrates, varying in organic matter content, to determine organic matter decomposition rates and the influence of both substrates and fertilizers on nutrient leaching.

\section{Conclusion}

Vegetative coverage was maintained for the duration of the study in all treatments; however, fertilized and control plots produced leachate nutrient concentrations greater than threshold levels outlined in Ontario and Canadian water quality guidelines. Although these guideline thresholds do not govern green roof runoff, the components of the green roof system used in this study should be evaluated in light of these thresholds to minimize environmental damage from nutrient loss. Only $\mathrm{NO}_{3}{ }^{-}$in all treatments and $\mathrm{Zn}$ in the $5 \mathrm{~g} \cdot \mathrm{m}^{-2} \mathrm{~N}$, Sus, and control treatment plots were below threshold levels. Therefore, changes to this green roof system, especially substrate composition, are needed to lower the negative environmental impact from nutrient leaching. Leachate EC levels were very high in the months after installation, indicating high levels of nutrient release, but were low after the first winter. Given the lower EC values observed for all treatments in 2012 compared with 2011, it appears much of the original substrate nutrient composition had been leached out before the 2012 growing season. The goal of a CRF application is to ensure nutrient availability during the growing season and an extended period of nutrient supply to green roof plants. However, in this green roof system, the combination of high substrate fertility and CRF application of 15 and $20 \mathrm{~g} \cdot \mathrm{m}^{-2} \mathrm{~N}$ resulted in greater total $\mathrm{Zn}$ leached after fertilization at $20 \mathrm{~g} \cdot \mathrm{m}^{-2} \mathrm{~N}$ than at $5 \mathrm{~g} \cdot \mathrm{m}^{-2} \mathrm{~N}$ (CRF and Sus) and the control. Vegetative coverage in 2012 did not significantly increase after fertilization below $10 \mathrm{~g} \cdot \mathrm{m}^{-2} \mathrm{~N}$ or above $15 \mathrm{~g} \cdot \mathrm{m}^{-2} \mathrm{~N}$, and Sedum spp. composition remained closest to the original when fertilized at $10 \mathrm{~g} \cdot \mathrm{m}^{-2} \mathrm{~N}$. Fertilization with rates at or above $15 \mathrm{~g} \cdot \mathrm{m}^{-2} \mathrm{~N}$ caused plants to experience winter injury damage and lower-leaf dieback. Based on plant performance data alone, a fertilizer rate of $10 \mathrm{~g} \cdot \mathrm{m}^{-2} \mathrm{~N}$ would be recommended to benefit this green roof system. However, to prevent negative environmental impacts, because all nutrients but $\mathrm{NO}_{3}{ }^{-}$in all treatments and $\mathrm{Zn}$ in the $5 \mathrm{~g} \cdot \mathrm{m}^{-2} \mathrm{~N}$ (CRF and Sus) and control treatments were leached at concentrations above the Canadian Council of Ministers of the Environment (2012) and the Ministry of the Environment and Energy (1994) thresholds, we do not recommend fertilizing this green roof system at installation. However, further research is needed to determine if post-installation fertilizer applications may be beneficial to this and other green roof systems with high initial substrate fertilities. For green roof systems varying in substrate composition, applying an appropriate fertilizer rate at installation may benefit plant growth and green roof performance. Therefore, applying fertilizer at installation may be suitable for some green roof systems such as a modular green roof system having a different growing substrate and species mix than used for the green roof mat system in this study (Clark and Zheng, 2013). However, an appropriate fertilizer rate should be considered in combination with the growing substrate characteristics and nutrient requirements of the plants within the green roof system.

In addition, when fertilizer type was considered, the Sus treatment leached a greater total amount of $P$ than all other treatments and had a similar plant growth response compared with application of $5 \mathrm{~g} \cdot \mathrm{m}^{-2} \mathrm{~N}$ CRF. Therefore, a Sus fertilizer application is not beneficial in this green roof system in the first year after installation. Further study is needed to confirm the long-term impact of this substrate alone or with Sus fertilizer applications in subsequent years on green roof plant performance and nutrient leaching. Because all components of a green roof system influence its success, recommendations for green roofs should consider the system as a whole when incorporating individual (i.e., fertilizer rate) recommendations. Overall, a CRF application at installation to a green roof with lower substrate nutrient levels than those of the growing substrate in this study could meet plant nutrition needs without causing excess nutrient leaching. These conclusions can aid both the design and maintenance of green roofs.

\section{Literature Cited}

Ampim, P.A.Y., J.J. Sloan, R.I. Cabrera, D.A. Harp, and F.H. Jaber. 2010. Green roof growing substrates: Types, ingredients, composition and properties. J. Environ. Hort. 28:244-252.

Barker, K.J. and J.D. Lubell. 2012. Effects of species proportions and fertility on Sedum green roof modules. HortTechnology 22:196200.

Benvenuti, S. and D. Bacci. 2010. Initial agronomic performances of Mediterranean xerophytes in simulated dry green roofs. Urban Ecosyst. 13:349-363.

Berndtsson, J.C. 2010. Green roof performance towards management of runoff water quantity and quality: A review. Ecol. Eng. 36:351-360.

Berndtsson, J.C., L. Bengtsson, and K. Jinno. 2009. Runoff water quality from intensive and extensive green roofs. Ecol. Eng. 35:369-380.

Boivin, M.-A., M.P. Lamy, A. Gosselin, and B. Dansereau. 2001. Effect of artificial substrate depth on freezing injury of six herbaceous perennials grown in a green roof system. HortTechnology 11:409-412.

Carter, T.L. and T.C. Rasmussen. 2006. Hydrologic behavior of vegetated roofs. J. Am. Water Resour. Assoc. 42:1261-1274.

Canadian Council of Ministers of the Environment. 2012. Canadian water quality guidelines for the protection of aquatic life: Nitrate. Canadian Council of Ministers of the Environment, Winnipeg, Manitoba, Canada.

Chen, J., Y. Huang, and R.D. Caldwell. 2001. Best management practices for minimizing nitrate leaching from container-grown nurseries. In Optimizing nitrogen management in food and energy production and environmental protection: Proceedings of the 2nd international nitrogen conference on science and policy. The ScientificWorld 1(suppl 2):96-102.

Clark, M.J. and Y. Zheng. 2012. Evaluating fertilizer influence on overwintering survival and growth of Sedum species in a fall-installed green roof. HortScience 47:1-7. 
Clark, M.J. and Y. Zheng. 2013. Plant nutrition requirements for an installed sedum-vegetated green roof module system: Effects of fertilizer rate and type on plant growth and leachate nutrient content. HortScience 48:1173-1180.

Cook-Patton, S.C. and T.L. Bauerle. 2012. Potential benefits of plant diversity on vegetated roofs: A literature review. J. Ecol. Mgt. 106:85-92.

Correll, D.L. 1998. The role of phosphorus in the eutrophication of receiving waters: A review. J. Environ. Qual. 27:261-266.

Currie, B.A. and B. Bass. 2008. Estimates of air pollution mitigation with green plants and green roofs using the UFORE model. Urban Ecosyst. 11:409-422.

Dunnett, N., A. Nagase, R. Booth, and P. Grime. 2008. Influence of vegetation composition on runoff in two simulated green roof experiments. Urban Ecosyst. 11:385-398.

Emilsson, T., J.C. Berndtsson, J.E. Mattsson, and K. Rolf. 2007. Effect of using conventional and controlled release fertilizer on nutrient runoff from various vegetated roof systems. Ecol. Eng. 29:260-271.

Fischer, P., and M. Jauch. 2002. Dränwasser in Trinkwasserqualität? Dach + Grün 4:24-31.

FLL. 2008. Guidelines for the planning, construction, and maintenance of green roofing - Green roofing guideline. Forschungsgesellschaft Landschaftsentwicklung Landschaftsbau, Bonn, Germany.

Getter, K.L. and D.B. Rowe. 2008. Media depth influences Sedum green roof establishment. Urban Ecosyst. 11:361-372.

Getter, K.L., D.B. Rowe, and J.A. Andresen. 2007. Quantifying the effect of slope on extensive green roof stormwater retention. J. Environ. Hort. 25:95-99.

Green Roofs for Healthy Cities. 2012. Annual green roof industry survey for 2011. 7 Feb. 2013. $<$ http://chesapeakestormwater.net/wp-content/ uploads/downloads/2012/05/2012GreenRoof IndustrySurvey.pdf $>$.

Gregoire, B.G. and J.C. Clausen. 2011. Effect of a modular extensive green roof on stormwater runoff and water quality. Ecol. Eng. 37:963969.

Hathaway, A.M., W.F. Hunt, and G.D. Jennings. 2008. A field study of green roof hydrologic and water quality performance. Trans. ASABE 51:37-44.

He, Z.L., X.E. Yang, and P.J. Stoffella. 2005. Trace elements in agroecosystems and impacts on the environment. J. Trace Elem. Med. Biol. 19:125140 .
Jones, J.B., Jr. 2012. Plant nutrition and soil fertility manual. 2nd Ed. CRC Press, Boca Raton, FL.

Kraus, H.T., R.L. Mikkelsen, and S.L. Warren. 2000. Container substrate temperatures affect mineralization of composts. HortScience 35 : 16-18.

Lee, D.W., J. O'Keefe, N.M. Holbrook, and T.S Field. 2003. Pigment dynamics and autumn leaf senescence in a New England deciduous forest, eastern USA. Ecol. Res. 18:677-694.

Marschner, H. 1995. Mineral nutrition of higher plants. 2nd Ed. Academic Press, London, UK.

Matile, P. 2000. Biochemistry of Indian summer: Physiology of autumnal leaf coloration. Exp. Gerontol. 35:145-158.

Matzner, E. and W. Borken. 2008. Do freeze-thaw events enhance $\mathrm{C}$ and $\mathrm{N}$ losses from soils of different ecosystems? A review. Eur. J. Soil Sci. 59:274-284.

Ministry of the Environment and Energy. 1994 Water management policies: Provincial water quality objectives. Queen's Printer for Ontario, Ontario, Canada.

Monterusso, M.A., D.B. Rowe, C.L. Rugh, and D.K. Russell. 2004. Runoff water quantity and quality from green roof systems. Acta Hort. 639:369-376.

Moran, A.C. 2004. A North Carolina field study to evaluate green roof runoff quantity, runoff quality, and plant growth. MS thesis, North Carolina State University, Department of Biological and Agricultural Engineering, Raleigh, NC.

Morgan, S., S. Celik, and W. Retzlaff. 2012. Green roof storm-water runoff quantity and quality. J. Environ. Eng. 139:471-478.

Nektarios, P., P. Tsiotsiopoulou, and I. Chronopoulos. 2004. Comparison of different roof garden substrates and their impact on plant growth. Acta Hort. 643:311-313.

Nektarios, P.A., I. Amountzias, I. Kokkinou, and N. Ntoulas. 2011. Green roof substrate type and depth affect the growth of the native species Dianthus fruticosus under reduced irrigation regimens. HortScience 46:1208-1216.

Oberndorfer, E., J. Lundholm, B. Bass, R.R. Coffman, H. Doshi, N. Dunnett, S. Gaffin, M. Kohler, K. Liu, and B. Rowe. 2007. Green roofs as urban ecosystems: Ecological structures, functions, and services. Bioscience 57 : 823-833.

Reed, D.W. 1996. A grower's guide to water, media, and nutrition for greenhouse crops. Ball Publishing, Batavia, IL.
Retzlaff, B., J. Gibbs-Alley, L. Swearingin, S. Morgan, V. Jost, and K. Luckett. 2009. Fertility options for green roofs. Proc. of Greening Rooftops for Sustainable Communities, Atlanta, GA.

Retzlaff, W., S. Ebbs, S. Alsup, S. Morgan, E. Woods, V. Jost, and K. Luckett. 2008. What is that running off my green roof? Proc. Green Roofs for Healthy Cities, Greening Rooftops for Sustainable Communities Conference, Baltimore, MD.

Rowe, D.B. 2011. Green roofs as a means of pollution abatement. Environ. Pollut. 159:2100 2110.

Rowe, D.B., M.A. Monterusso, and C.L. Rugh. 2006. Assessment of heat-expanded slate and fertility requirements in green roof substrate. HortTechnology 16:471-477.

Russell, R.S. 1977. Plant root systems. McGraw Hill, UK.

Sailor, D.J. 2008. A green roof model for building energy simulation programs. Energy Build. 40:1466-1478.

Snodgrass, E.C. and L.L. Snodgrass. 2006. Green roof plants: A resource and planting guide. Timber Press, Portland, OR.

Tan, P.Y. and A. Sia. 2009. Understanding the performance of plants on non-irrigated green roofs in Singapore using a biomass yield approach. Nat. Singapore. 2:149-153.

Tonietto, R., J. Fant, J. Ashcher, K. Ellis, and D. Larkin. 2011. A comparison of bee communities of Chicago green roofs, parks, and prairies. Landsc. Urban Plan. 103:102-108.

Van Seters, T., L. Rocha, D. Smith, and G. MacMillan. 2009. Evaluation of green roofs for runoff retention, runoff quality, and leachability. Water Qual. Res. J. Canada 44:33-47.

VanWoert, N.D., D.B. Rowe, J.A. Andresen, C.L. Rugh, R.T. Fernandez, and L. Xiao. 2005. Green roof stormwater retention: Effects of roof surface, slope, and media depth. J. Environ. Qual. 34:1036-1044.

Vollenweider, P. and M.S. Gunthardt-Goerg. 2005. Diagnosis of abiotic and biotic stress factors using the visible symptoms in foliage. Environ. Pollut. 137:455-465.

Wolf, D. and J.T. Lundholm. 2008. Water uptake in green roof microcosms: Effects of plant species and water availability. Ecol. Eng. 33:179-186.

Wright, R.D. 1986. The pour through nutrient extraction procedure. HortScience 21:227229.

Zheng, Y. and M.J. Clark. 2013. Optimal growing substrate $\mathrm{pH}$ for five Sedum species. HortScience 48:448-452. 